\title{
Phenotypic Responses to Selection for Ultrafine Wool in Uruguayan Yearling Lambs
}

\author{
Zully Ramos ${ }^{1, *}$, Hugh Thomas Blair ${ }^{1}$, Ignacio De Barbieri ${ }^{2} \oplus$, Gabriel Ciappesoni ${ }^{2}$, Fabio Montossi ${ }^{2}$ \\ and Paul Richard Kenyon ${ }^{1}$ \\ 1 School of Agriculture and Environment, Massey University, Private Bag 11222, \\ Palmerston North 4410, New Zealand; H.Blair@massey.ac.nz (H.T.B.); P.R.Kenyon@massey.ac.nz (P.R.K.) \\ 2 Estación Experimental INIA Tacuarembó, Instituto Nacional de Investigación Agropecuaria, Ruta 5 km 386, \\ Tacuarembó 45000, Uruguay; idebarbieri@inia.org.uy (I.D.B.); gciappesoni@inia.org.uy (G.C.); \\ fmontossi@inia.org.uy (F.M.) \\ * Correspondence: Z.RamosAlvez@massey.ac.nz
}

check for updates

Citation: Ramos, Z.; Blair, H.T.; De Barbieri, I.; Ciappesoni, G.; Montossi, F.; Kenyon, P.R. Phenotypic Responses to Selection for Ultrafine Wool in Uruguayan Yearling Lambs. Agriculture 2021, 11, 179. https:// doi.org/10.3390/agriculture11020179

Academic Editor: Wayne L. Bryden

Received: 28 January 2021

Accepted: 19 February 2021

Published: 22 February 2021

Publisher's Note: MDPI stays neutral with regard to jurisdictional claims in published maps and institutional affiliations.

Copyright: (c) 2021 by the authors. Licensee MDPI, Basel, Switzerland. This article is an open access article distributed under the terms and conditions of the Creative Commons Attribution (CC BY) license (https:// creativecommons.org/licenses/by/ $4.0 /)$.

\begin{abstract}
This study evaluated the phenotypic trends for wool and growth traits of the fine Merino genetic nucleus in Uruguay. Data were collected from one-year-old lambs over a twenty-year period (1999-2018). The overall aim of the selection flock was to reduce fiber diameter with concomitant increases in fleece and live weights. Traits analyzed included fiber diameter (FD), greasy fleece weight (GFW), coefficient of variation of FD (CVfd), staple length (SL), scoured yield (SY), live weight post-shearing (LW), eye muscle area (EMA) and fat thickness (FAT). Data from approximately 5300 one-year-old male and female lambs were analyzed. During the study period, FD decreased by approximately $3 \mu \mathrm{m}$, whereas GFW and LW increased by at least 0.5 and $3.0 \mathrm{~kg}$, respectively. There were interactions between the sex of the individual and the year for all wool traits. Except for FAT, all other traits were affected by the dam age. This study indicates that the selection program applied in the fine Merino genetic nucleus over a twenty-year period resulted in reductions in FD and increases in GFW and LW. Therefore, the results indicate it is possible to produce ultrafine wool in semi-extensive grazing systems without compromising other economically relevant traits in one-year-old lambs.
\end{abstract}

Keywords: sheep; ultrafine; selection; wool; live weight

\section{Introduction}

During the early 1990s, the Uruguayan sheep industry was focused on wool production, with less emphasis on lamb meat [1]. At this time, revenue from wool accounted for approximately $70 \%$ of total sheep farmer income [1]. The Corriedale breed represented $70.5 \%$ of the national flock, followed by Polwarth (11.6\%), Australian Merino (8.4\%), Merilin (3.2\%), Romney (1.0\%) and crossbreeds (5.3\%) [1]. Due to the national sheep breed composition, mid-micron wool $(25.0-30.0 \mu \mathrm{m})$ was the most abundant wool type (approximately $70 \%$ ) [1]. Lambing occurred predominantly over the winter-early spring (July-September) period, with lamb marking percentage ((number of lambs at approximately one-month of age/number of ewes joined) $\times 100)$ ) ranging between $65 \%$ and $85 \%$ [2]. During the early 1990s, the wool price was the main factor influencing sheep farmer decision-making [1].

In parallel, the world textile industry faced changing consumer preference trends [3,4]. The demand for mid-micron wool $(25.0-30.0 \mu \mathrm{m})$ declined significantly to the point where its production became uneconomical $[1,2,5,6]$. Since the early 1990s, the Australian Merino wool industry has undergone significant changes, resulting in an increase in finer wool production (18.6 to $19.5 \mu \mathrm{m}$ ) at the expense of medium diameter (19.6 to $22.5 \mu \mathrm{m}$ ) Merino wool [7]. This was driven primarily by wool value on a per $\mathrm{kg}$ basis, with superfine $(15.6-18.5 \mu \mathrm{m})$ wool obtaining the highest value [7-9]. Uruguayan wool prices were de- 
pendent on international market trends, especially those registered in Australia [10], and therefore changes were needed.

During the late 1990s, the mean fiber diameter of Uruguayan Merino wool was approximately $22 \mu \mathrm{m}$, with insignificant amounts of fine and superfine wool [11]. To differentiate and add value to Uruguayan Merino wools, by producing finer, more valuable wool, in 1998, the Uruguayan Wool Secretariat (SUL), Association of the Uruguayan Merino Breeders of Uruguay (SCMAU), National Institute for Agriculture Research (INIA) and 36 Merino sheep farmers developed the fine Merino Project (FMP, 1999-2010) [12]. One of the objectives of the FMP was to develop a fine Merino genetic nucleus, located at Glencoe Experimental Unit of INIA Tacuarembó Research Station, specialized in producing fine wool (less than $19.5 \mu \mathrm{m}$ ), generating genetically superior rams to be distributed to commercial farms throughout Uruguay. At the end of the FMP in 2010, the market price trends favored the ultrafine wool type $(15.5 \mu \mathrm{m}$ or finer) [9]. In response to those wool price trends and market scenarios, the fine Merino genetic nucleus continued as part of a new project entitled Uruguayan Regional Consortium for Innovation in Ultrafine Wool (CRILU, 2011-2021) [13]. This consortium has been run by an increased number of farmers (42), INIA, and wool top makers of Uruguay.

The overall breeding objective of the FMP project (1999-2010) was to reduce fiber diameter while allowing for only a slight loss in fleece weight. During the CRILU phase (2011-2018), the selection objective was to continue to reduce fiber diameter (to produce $15.5 \mu \mathrm{m}$ or finer wool) while improving both fleece weight and live weight. This paper aims to evaluate the phenotypic trends observed over the period 1999 to 2018 in economically relevant fleece and growth traits of the fine Merino genetic nucleus offspring to one-year-old of age.

\section{Materials and Methods}

\subsection{Background, Period, and Location}

The foundation fine Merino genetic nucleus was established at the Glencoe Experimental Unit of National Institute for Agriculture Research of Uruguay (INIA) $\left(32^{\circ} 00^{\prime} 21^{\prime \prime} \mathrm{S}\right.$ and $57^{\circ} 08^{\prime} 06^{\prime \prime} \mathrm{W}$ ) in 1999. In this region, the average annual rainfall ranges between 1000 to $1300 \mathrm{~mm}$, with high variability between years [14]. Annual pasture production fluctuates between 2885 and $4580 \mathrm{~kg}$ of dry matter (DM)/ha, being the highest production in summer and spring, while winter production accounts for only $15 \%$ of the total DM production [15].

This study combined data from two research projects carried out in the fine Merino genetic nucleus between 1999 to 2018. To evaluate the information corresponding to each project, the entire study period was classified into three phases: Establishment (1999-2001), FMP (2002-2010), and CRILU (2011-2018). In this study, we analyze the information from one-year-old lambs only.

\subsection{Selection of Original Fine Merino Genetic Nucleus' Animals}

The selection of the original ewes occurred in two stages. In the winter of 1998 (first phase), approximately 742 ewes were preselected from 5171 ewes (18 to 30 months of age) provided by 36 Merino stud breeders and/or commercial farmers. Subjective criteria, including conformation traits (i.e., leg, feet, shoulder, back, jaw, size and face cover) and wool quality traits (i.e., fleece rot, wool color and character, staple structure, black wool and skin spots, fiber pigmentation and non-fiber pigmentation) were utilized for preselection of the fine Merino genetic nucleus [16,17]. In the spring shearing of 1998 (second phase), a wool sample was obtained of preselected ewes (742) and tested by a wool testing laboratory (Uruguayan Wool Secretariat, Montevideo, Uruguay) for the fiber diameter (FD). Additionally, greasy fleece weight (GFW) and live weight (LW) were recorded. These three objective criteria (FD, GFW and LW) were used to select 475 ewes, which then finally formed the fine Merino genetic nucleus [11].

To source rams for the formation of the fine Merino genetic nucleus, approximately 40 Merino stud breeders across Australia and New Zealand were visited. Rams were 
preselected according to visual inspection in situ, their genetic merit for most relevant economic production traits (FD, clean fleece weight and LW), the genetic trends of stud flocks and the technical advice done by the Australian genetic evaluation staff. Later, frozen semen from the selected rams was imported into Uruguay and utilized (Table 1). Uruguayan rams were also utilized to connect the fine Merino genetic nucleus with the Merino Progeny Testing Centers of Uruguay (Table 1).

Table 1. Total annual number of ewes, percentage of ewe replacement by ewe hoggets and number of sires utilized in the fine Merino genetic nucleus over the entire study period (1999-2018).

\begin{tabular}{|c|c|c|c|c|c|c|}
\hline \multirow{2}{*}{ Phase } & \multirow{2}{*}{ Year } & \multirow{2}{*}{$\begin{array}{c}\mathrm{N}^{\circ} \text { of } \\
\text { Ewes } 1\end{array}$} & \multirow{2}{*}{$\begin{array}{c}\text { Replacement Ewe } \\
\text { Hoggets }(\%)^{2}\end{array}$} & \multicolumn{3}{|c|}{$\mathrm{N}^{0}$ of Sires ${ }^{3}$} \\
\hline & & & & Imp. ${ }^{4}$ & Nucleus $^{5}$ & Nat. ${ }^{6}$ \\
\hline \multirow{3}{*}{ Establishment } & 1999 & 456 & - & 6 & - & 3 \\
\hline & 2000 & 434 & - & 6 & - & 2 \\
\hline & 2001 & 488 & 28 & 6 & 2 & - \\
\hline \multirow{9}{*}{ FMP } & 2002 & 484 & 18 & 8 & 5 & - \\
\hline & 2003 & 465 & 20 & 8 & 5 & - \\
\hline & 2004 & 460 & 18 & 4 & 6 & - \\
\hline & 2005 & 478 & 25 & 3 & 6 & - \\
\hline & 2006 & 394 & 31 & 6 & 7 & - \\
\hline & 2007 & 392 & 31 & 2 & 7 & - \\
\hline & 2008 & 362 & 35 & 3 & 7 & - \\
\hline & 2009 & 409 & 29 & 3 & 5 & - \\
\hline & 2010 & 477 & 27 & 1 & 6 & - \\
\hline \multirow{8}{*}{ CRILU } & 2011 & 403 & 21 & 1 & 6 & - \\
\hline & 2012 & 398 & 27 & 1 & 6 & - \\
\hline & 2013 & 382 & 29 & 2 & 6 & - \\
\hline & 2014 & 327 & 27 & 2 & 9 & - \\
\hline & 2015 & 358 & 25 & 4 & 5 & - \\
\hline & 2016 & 349 & 17 & - & 6 & - \\
\hline & 2017 & 319 & 20 & 2 & 8 & - \\
\hline & 2018 & 369 & 33 & 3 & 9 & - \\
\hline
\end{tabular}

${ }^{1} \mathrm{~N}^{\circ}$ of ewes: total ewes of the nucleus (including ewe hoggets and ewes), ${ }^{2}$ replacement ewe hoggets selected (\%) $=$ the number of ewe hoggets at 18 months of age/total ewes in the nucleus flock $\times 100 .{ }^{3} \mathrm{~N}^{\circ}$ of sires: total sires of the nucleus per year. Total sires of the nucleus $=78$ rams (some sires were used for more than one year), ${ }^{4}$ Imp: number of rams utilized as imported semen. ${ }^{5}$ nucleus: number of rams utilized and born within the nucleus.

${ }^{6}$ Nat: number of rams utilized from local Merino stud breeders.

\subsection{Fine Merino Genetic Nucleus: Genetic Selection}

At approximately one year of age, male and female offspring born in the fine Merino genetic nucleus were evaluated to determine if they would be subsequently selected as replacement animals. The animal selection process included phenotypic and genetic criteria. First, prior to shearing (early September, at approximately 11 months of age), all lambs were phenotypically evaluated and classified in one of the three global scores (1-3) based on the animal's conformation and wool traits as previously reported [16]. The scores 1 and 3 corresponded to the top individuals and cull animals, respectively, while a score of 2 was a phenotypically acceptable animal to use in commercial flocks.

Since 1995, estimated breeding values (EBVs) for several productive traits for Merino sheep have been generated by the Uruguayan national genetic evaluation scheme [18] and were utilized to calculate EBVs for the fine Merino genetic nucleus. Additionally, at the beginning of the FMP, the EBVs for CFW and FD were combined to generate two selection indexes for the Uruguayan Merino genetic evaluation. Index II emphasized FD-reduction while allowing for a slight loss in CFW, which in turn was applied as selection criteria across the establishment and FMP periods (1999-2010). In response to new wool and meat price scenarios, in 2011, the EBVs for FD, CFW and LW were combined into three new selection indexes (fine wool, wool and dual-purpose alternative options), representing different breeding objectives [19]. The fine wool index aimed to decrease FD and increase both CFW 
and LW [20] and was utilized as the selection criteria during the CRILU development phase (2011-2018). At this period, looking for sheep resistance to gastrointestinal nematodes, EBVs for fecal worm egg count were utilized as a complementary selection criterion.

In addition to phenotypic and genetic criteria, potential male and female animal replacements were clinically examined to detect anatomic anomalies that could potentially compromise reproductive performance (e.g., teeth, mouth, foot, reproductive organs). In males, bloodlines of their parents were also considered for avoiding inbreeding. This selection tool became more relevant as more parents from the nucleus were utilized for breeding. Each year approximately three phenotypically acceptable rams (phenotypic global score 1 or 2), with the highest genetic merit (based on high index II or fine wool index), were selected to be utilized as rams in the fine Merino genetic nucleus.

During the establishment phase (1999-2001), ewes were inseminated mostly with imported frozen semen (Table 1), using six Australian rams each year. In 2001, two nucleusborn rams were utilized as sires. As more rams from the nucleus became available, the use of imported semen was gradually reduced and substituted by nucleus-born rams. During the CRILU phase (2011-2018), most of the rams utilized were born in the fine Merino genetic nucleus. From 2001 to 2018, the percentage ewe hoggets selected ((number of ewe hoggets at 18 months of age/total ewes of the nucleus) $\times 100$ ) each year as female replacements ranged between 18 and 35\% of the nucleus. In addition, from 2004 to 2014, superovulation reproductive treatments were applied on a maximum of 14 ewes per year.

\subsection{Fine Merino Genetic Nucleus: Nutrition and Animal Management}

Ewe nutrition was based on native pastures with restricted access to improved pastures (a mix of white clover, annual ryegrass or oats and lotus corniculatus) or supplementation (sorghum, soybean, corn, commercial rations, among others) during the highest dam nutrition requirement phases, such as the last third of gestation and in early lactation. Lambing occurred in spring, predominantly over the September and October period. Ewes in late pregnancy were monitored $24 \mathrm{~h}$ a day by qualified field staff (which rotated at eight-hour intervals). Lambing was outdoors on improved pastures. After the ewe-lamb(s) bond was established, lambs and their dams were placed indoors into individual pens with ad libitum access to water and lucerne hay [21]. Lambs and ewes remained in the indoor pens for a period of 12 to $24 \mathrm{~h}$, depending on environmental conditions, their health status and the mother-lamb(s) bond. When environmental conditions were suitable, both the ewes and their lamb(s) were moved back outdoors into improved pastures with other ewes lambed.

New-born lambs were ear-tagged with an identification number and weighed within $12 \mathrm{~h}$ of birth. Additional information collected included: dam identification, lamb status (anomalies or dead), sex of the lamb and birth rank (single, twin or triplet). At approximately one month of age, lambs were marked (notch in the ear with the owner mark), tattooed (print of the individual identification number on the inside of the ear), weighed and immunized with the first Clostridium vaccine dose (Sintoxan ${ }^{\circledR}$ 9TH or Ultravac ${ }^{\circledR}$, Merial, Montevideo, Uruguay), receiving a second Clostridium vaccine dose approximately 30 days later. Additionally, at approximately one month of age, the tail of each lamb was removed using mostly the rubber ring method according to the procedure described by others [22]. In 2018, at approximately $48 \mathrm{~h}$ post-birth, the tail was docked using rubber rings.

Weaning occurred at approximately 3.5 months of age (during the December-February period). During summer, when improved pasture availability and quality were limited, lambs grazing native pasture had access to supplementation (at a rate of 1 to $1.5 \% \mathrm{LW}$ ) using a commercial grain-based ration, which was approximately $18-21 \%$ crude protein. During autumn, winter and spring, male lambs were managed mostly on improved pastures (a mix of white clover, annual ryegrass or oats and lotus corniculatus) plus supplement (rice bran, soybean, corn and commercial rations) as required. Replacement female lambs were managed with the main target of achieving an LW at first mating (at approximately 
18 months of age) greater than $80 \%$ of mature LW [17]. Their nutrition was mostly based on native pasture with the complementary use of a supplement, if necessary.

Internal parasite control was done by oral drench with an effective anthelmintic complemented by different prevention strategies (safe pastures, rotative grazing, grazing with beef cattle). All lambs were drenched orally at weaning (December-February). Subsequently, fecal samples of ten random lambs were collected monthly for gastrointestinal nematode egg count. Whenever the average number of eggs was greater than 800 per gram of feces, all animals were drenched. All lambs were reimmunized with a clostridial vaccine (Sintoxan ${ }^{\circledR}$ 9TH or Ultravac ${ }^{\circledR}$, Merial, Montevideo, Uruguay) every six months, and annually treated for external parasites (Mixan ${ }^{\circledR}$, La Buena Estrella or Elimix ${ }^{\circledR}$, Nutritec, Montevideo, Uruguay).

\subsection{Measurements}

Data were collected on one-year-old lambs over a twenty-year period (1999-2018). Prior to shearing (early September) at approximately 12 months of age, a patch of approximately $10 \times 10 \mathrm{~cm}$ was clipped on the mid-flank position of each lamb [23]. Clipped wool was individually bagged, identified and weighed. All samples were sent to a wool testing laboratory (Uruguayan Wool Secretariat, Montevideo, Uruguay), where FD, SL and scoured yield (SY) were assessed (Table 2). SL and SY were estimated utilizing the methods described by others [24]. FD was measured following norms IWTO 52 (IWTO, 2006) and 12 (IWTO, 2012b). Shearing occurred in spring, predominantly over the September and October period using the Tally-Hi method and green label protocol [25]. At shearing, the GFW of each lamb was recorded, and approximately within one-week post-shearing, all lambs were weighed (LW). From 2010, at approximately 13 months of age (October), eye muscle area (EMA) and fat thickness (FAT) of each lamb were measured at the Longissimus thoracis et lumborum muscle by ultrasound technique as previously described by others [24]. The wool and growth traits analyzed in the present study are summarized in Table 2.

Table 2. Age of the animal, time of the measurements and data recorded in one-year-old female and male lambs (1999-2018).

\begin{tabular}{|c|c|c|}
\hline Traits & Age (Months) & Time \\
\hline $\begin{array}{c}\text { Wool traits } \\
\text { Fiber diameter (FD, } \mu \mathrm{m}) \\
\text { Greasy fleece weight }(\mathrm{GFW}, \mathrm{kg}) \\
\text { Coefficient of variation of FD }(\mathrm{CVfd}, \%) \\
\text { Staple length (SL, cm) } \\
\text { Scoured yield (SY, \%) } \\
\text { Growth traits }\end{array}$ & 12 & $\begin{array}{l}\text { Shearing } \\
\text { (Sept-Oct) }\end{array}$ \\
\hline $\begin{array}{c}\text { Live weight }(\mathrm{LW}, \mathrm{kg}) \\
\left.\text { Eye muscle area (EMA, } \mathrm{cm}^{2}\right) \\
\text { Fat thickness }(\mathrm{FAT}, \mathrm{mm})\end{array}$ & 13 & $\begin{array}{c}\text { Post-shearing } \\
\text { (Sept-Oct) }\end{array}$ \\
\hline
\end{tabular}

\subsection{Statistical Analysis}

Data were analyzed utilizing a general linear model (Proc GLM) in SAS (version 9.4, SAS Institute Inc., Cary, NC, USA). Outliers detection based on a robust regression model (PROC ROBUSTREG) was performed on each trait, and corresponding outliers were removed. This procedure computes a robust version of the Mahalanobis distance by using a generalized minimum covariance determinant method. The model for one-year-old lamb wool traits included "year", "sex of the individual", "birth-rearing rank" (born as single and weaned as single -S/S- or born as multiple and either weaned as single -M/S- or multiple -M/M-), and "dam age" (2-year-old, 3 to 6 years old and aged 7 or older) as fixed effects and "age at shearing" (298 to 432 days of age) as a covariate. Two-way interactions between sex of the lamb and year and birth-rearing rank and sex of the lamb were also included in the model even if they were not significant $(p>0.05)$. 
The model for one-year-old lamb live weight post-shearing was as described for wool traits but replacing "age at shearing" with "age at LW" (321 to 438 days of age). This model was then repeated, adding the sex of the individual nested within year. EMA and FAT data were recorded in 2010, 2011 and from 2013 to 2018. The model for ultrasound measurements was as described for live weight but replacing "age at LW" with "age at ultrasound measurements" (355 to 435 days of age). Live weight at the ultrasound measurements time was also tested as a covariate. Means were compared using the TukeyKramer test, which was considered significantly different when $p<0.05$. Non-significant interactions are not shown in the results section.

FD, GFW and LW post-shearing (321 to 438 days of age) trends were evaluated utilizing an orthogonal polynomial regressions model (Proc ORTHOREG) in SAS (version 9.4, SAS Institute Inc., Cary, NC). The order of the polynomial regression utilized was based on the coefficient of determination value $\left(R^{2}\right)$ (results not shown). To explore the relationship between FD and dependent factors (year, sex of the lamb, birth-rearing rank, dam age, age at shearing and the two-way interactions between sex of the lamb and year and birth-rearing rank and sex of the lamb), a second-degree polynomial regression model was utilized. The regression model for GFW and LW post-shearing (321 to 438 days) was as described by FD, but for these two traits, a third-degree polynomial was applied. The polynomial regressions model was performed for all progeny (i.e., males and females together) and for each sex separately, and a 95\% confidence interval (CI) calculated.

\section{Results}

Summary statistics for wool and growth traits are presented in Table 3. Over the period 1999 to 2018, mean FD, GFW and LW ranged between 14.4 to $18.9 \mu \mathrm{m}, 1.9$ to $4.2 \mathrm{~kg}$ and 40.1 to $53.3 \mathrm{~kg}$, respectively (Table 4 ). The standard deviation values fluctuated between 0.8 to $1.2 \mu \mathrm{m}, 0.3$ to $0.9 \mathrm{~kg}$ and 6.2 to $13.2 \mathrm{~kg}$ for FD, GFW and LW, respectively.

Table 3. Descriptive statistics for the combined one-year-old female and male wool and growth traits (1999-2018).

\begin{tabular}{cccccc}
\hline Traits & Mean & Min & Max $^{\mathbf{2}}$ & SD $^{\mathbf{3}}$ & $\mathbf{n}^{\mathbf{4}}$ \\
\hline Wool traits & & & & & \\
Fiber diameter (FD, $\mu \mathrm{m})$ & 15.8 & 12.4 & 21.2 & 1.5 & 5361 \\
Greasy fleece weight (GFW, kg) & 3.1 & 1.2 & 6.2 & 0.9 & 5367 \\
Coef. of variation of FD (CVfd, \%) & 17.6 & 11.3 & 24.6 & 2.2 & 5052 \\
Staple length (SL, cm) & 8.4 & 3.5 & 14.0 & 1.8 & 5405 \\
Scoured yield (SY, \%) & 75.5 & 61.7 & 88.7 & 4.5 & 5390 \\
Growth traits & & & & & \\
Live weight post-shearing (LW, $\mathrm{kg}$ ) & 45.0 & 18.5 & 75.5 & 10.5 & 5402 \\
Eye muscle area (EMA, cm ${ }^{2}$ ) & 10.0 & 3.7 & 17.2 & 2.6 & 2042 \\
Fat thickness (FAT, mm) & 2.8 & 1.0 & 6.0 & 0.9 & 2019 \\
\hline
\end{tabular}

\footnotetext{
1,2,3 Min, Max, and SD correspond to minimum, maximum, and standard deviation values for each
} trait. ${ }^{4} \mathrm{n}$ : number of records. 
Table 4. Annual mean, standard deviation and number of records of fiber diameter, greasy fleece weight at shearing (298 to 432 days of age), and live weight post-shearing (321 to 438 days of age) for the combined one-year-old female and male lambs (1999-2018).

\begin{tabular}{|c|c|c|c|c|c|c|c|c|c|c|}
\hline \multirow{2}{*}{ Phase } & \multirow{2}{*}{ Year } & \multicolumn{3}{|c|}{ Fibre Diameter $(\mu \mathrm{m})$} & \multicolumn{3}{|c|}{ Greasy Fleece Weight (kg) } & \multicolumn{3}{|c|}{ Live Weight (kg) } \\
\hline & & Mean & S.D ${ }^{1}$ & $\mathrm{~N}^{2}$ & Mean & S.D ${ }^{1}$ & $n^{2}$ & Mean & S.D ${ }^{1}$ & $n^{2}$ \\
\hline \multirow{3}{*}{ Establishment } & 1999 & 17.9 & 1.2 & 328 & 3.1 & 0.5 & 327 & 40.1 & 6.7 & 332 \\
\hline & 2000 & 17.4 & 1.2 & 242 & 2.3 & 0.4 & 247 & 40.9 & 8.4 & 248 \\
\hline & 2001 & 18.2 & 1.2 & 207 & 2.8 & 0.6 & 219 & 47.3 & 10.3 & 219 \\
\hline \multirow{9}{*}{ FMP } & 2002 & 18.9 & 1.1 & 160 & 3.4 & 0.7 & 178 & 53.3 & 10.2 & 186 \\
\hline & 2003 & 16.6 & 1.1 & 334 & 2.2 & 0.4 & 334 & 48.3 & 9.5 & 329 \\
\hline & 2004 & 15.9 & 1.2 & 286 & 1.9 & 0.3 & 290 & 43.1 & 6.2 & 292 \\
\hline & 2005 & 16.0 & 1.2 & 344 & 2.6 & 0.5 & 345 & 42.6 & 7.2 & 345 \\
\hline & 2006 & 15.4 & 1.1 & 309 & 2.8 & 0.6 & 309 & 41.1 & 7.8 & 298 \\
\hline & 2007 & 15.5 & 1.0 & 256 & 3.0 & 0.5 & 256 & 44.0 & 10.1 & 254 \\
\hline & 2008 & 15.3 & 1.1 & 306 & 3.2 & 0.7 & 300 & 42.2 & 7.9 & 309 \\
\hline & 2009 & 14.4 & 0.9 & 269 & 2.5 & 0.5 & 270 & 40.1 & 8.2 & 269 \\
\hline & 2010 & 15.6 & 1.0 & 303 & 3.9 & 0.7 & 295 & 51.0 & 10.8 & 304 \\
\hline \multirow{8}{*}{ CRILU } & 2011 & 15.1 & 1.0 & 364 & 3.6 & 0.9 & 344 & 46.0 & 13.2 & 368 \\
\hline & 2012 & 15.6 & 1.0 & 268 & 4.1 & 0.8 & 266 & 48.8 & 10.3 & 268 \\
\hline & 2013 & 14.8 & 1.0 & 279 & 3.2 & 0.7 & 281 & 41.3 & 11.7 & 282 \\
\hline & 2014 & 15.0 & 0.8 & 151 & 3.1 & 0.5 & 150 & 43.9 & 7.7 & 151 \\
\hline & 2015 & 14.6 & 0.8 & 196 & 3.2 & 0.6 & 197 & 45.2 & 12.6 & 196 \\
\hline & 2016 & 15.1 & 1.0 & 243 & 3.7 & 0.8 & 246 & 49.6 & 12.9 & 243 \\
\hline & 2017 & 15.3 & 0.9 & 231 & 3.7 & 0.8 & 230 & 46.2 & 11.6 & 229 \\
\hline & 2018 & 15.0 & 0.9 & 285 & 4.2 & 0.7 & 283 & 48.4 & 10.4 & 280 \\
\hline
\end{tabular}

1,2 S.D and $\mathrm{n}$ correspond to standard deviation value and number of records for each trait each year, respectively.

\subsection{Effects of Sex of Individual on Wool and Growth Traits}

There were interactions between the sex of the lamb and the year for all wool traits $(p<0.05$, Table 5). In 2004, 2005 and 2018, mean FD did not differ $(p>0.05)$ between the sexes, but in 1999 females had coarser fibers than males, whereas, in all other years, males had coarser $(0.5 \mu \mathrm{m}$ extra) fibers than females $(p<0.05)$. In 1999 and 2004, GFW was not affected by the sex of the individual $(p>0.05)$, but in all other years, males produced heavier $(p<0.05)$ fleeces than females. In 1999, 2001, and from 2003 to 2007, and 2010 to 2012 and in 2014, sex of the lamb had no effect $(p>0.05)$ on SL, whereas, in 2017, the females had longer fibers ( $3 \%$ extra, $p<0.05)$ than males, but in all other years, fibers were longer $(p<0.05)$ in males than females. In 2004, 2007, 2008, and from 2010 to 2012, and 2014 to 2017, CVfd was not affected by the sex of the individual ( $p>0.05)$, but in 2001 and 2013 , females had greater (4 and 3\% extra, respectively, $p<0.05$ ) CVfd than males, whereas in all other years CVfd was greater $(p<0.05)$ in males. In 2001, 2005, 2007, 2008 and 2016, SY did not differ $(p>0.05)$ between the sexes, whereas in 2006, 2014 and 2018 males had higher $(2.0,2.2$ and $3.5 \%$ extra, respectively, $p<0.05)$ SY than females, and in all other years, females had higher $(p<0.05) \mathrm{SY}$. 




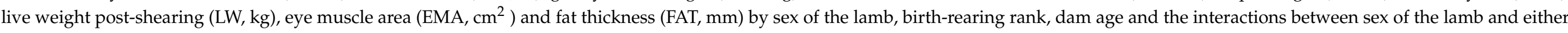
year or birth-rearing rank (1999-2018)

\begin{tabular}{|c|c|c|c|c|c|c|c|c|c|c|c|c|c|}
\hline \multirow{2}{*}{ Traits } & \multicolumn{2}{|c|}{ Sex of the Lamb } & \multirow{2}{*}{ SEM } & \multicolumn{3}{|c|}{ Birth-Rearing Rank $^{1}$} & \multirow{2}{*}{ SEM } & \multicolumn{3}{|c|}{ Dam Age (Years) } & \multirow{2}{*}{ SEM } & \multicolumn{2}{|c|}{ Interactions } \\
\hline & Male & Female & & $\mathrm{S} / \mathrm{S}$ & $\mathbf{M} / \mathbf{S}$ & $\mathbf{M} / \mathbf{M}$ & & 2 & 3 to 6 & $\geq 7$ & & $\mathrm{Y} / \mathrm{S}^{2}$ & $\mathrm{BRR} / \mathrm{S}^{3}$ \\
\hline Fibre diameter $(\mathrm{FD}, \mu \mathrm{m})$ & $16.1^{\mathrm{a}}$ & $15.6^{\mathrm{b}}$ & 0.05 & 15.9 & 15.8 & 15.9 & 0.06 & $15.6^{\mathrm{c}}$ & $15.9^{b}$ & $16.1^{\mathrm{a}}$ & 0.05 & * & NS \\
\hline Greasy fleece weight (GFW, kg) & $3.3^{\mathrm{a}}$ & $2.6^{\mathrm{b}}$ & 0.02 & $3.2^{\mathrm{a}}$ & $2.9^{b}$ & $2.8^{\mathrm{c}}$ & 0.03 & $2.9^{b}$ & $3.0^{\mathrm{a}}$ & $3.0^{a b}$ & 0.02 & * & * \\
\hline Coef. of variation of FD (CVfd, \%) & $17.8^{\mathrm{a}}$ & $17.5^{\mathrm{b}}$ & 0.08 & $17.4^{\mathrm{b}}$ & $17.6^{\mathrm{b}}$ & $17.9^{\mathrm{a}}$ & 0.10 & $17.5^{\mathrm{b}}$ & $17.6^{\mathrm{b}}$ & $17.9^{\mathrm{a}}$ & 0.09 & * & NS \\
\hline Staple length (SL, cm) & $8.5^{\mathrm{a}}$ & $8.3^{b}$ & 0.05 & 8.4 & 8.5 & 8.4 & 0.06 & $8.7^{\mathrm{a}}$ & $8.3^{b}$ & $8.3^{\mathrm{b}}$ & 0.06 & * & NS \\
\hline Scoured yield (SY, \%) & $74.3^{\mathrm{b}}$ & $75.8^{\mathrm{a}}$ & 0.17 & $75.5^{\mathrm{a}}$ & $75.0^{\mathrm{b}}$ & $74.6^{\mathrm{b}}$ & 0.20 & $75.3^{\mathrm{a}}$ & $75.4^{\mathrm{a}}$ & $74.4^{b}$ & 0.19 & * & NS \\
\hline Live weight post shearing (LW, kg) & $52.5^{a}$ & $36.4^{\mathrm{b}}$ & 0.22 & $46.0^{\mathrm{a}}$ & $44.5^{\mathrm{b}}$ & $43.0^{\mathrm{c}}$ & 0.27 & $43.4^{\mathrm{b}}$ & $44.8^{\mathrm{a}}$ & $45.3^{\mathrm{a}}$ & 0.26 & NS & $*$ \\
\hline Eye muscle area (EMA, $\left.\mathrm{cm}^{2}\right)$ & $11.9^{\mathrm{a}}$ & $8.1^{b}$ & 0.09 & $10.1^{\mathrm{a}}$ & $10.2^{\mathrm{a}}$ & $9.9^{b}$ & 0.10 & $9.9^{b}$ & $10.0^{\mathrm{b}}$ & $10.3^{\mathrm{a}}$ & 0.10 & NS & * \\
\hline Eye muscle area (EMA, $\left.\mathrm{cm}^{2}\right)^{\mathrm{LW}}$ & $10.7^{\mathrm{a}}$ & $9.6^{b}$ & 0.13 & $10.0^{\mathrm{b}}$ & $10.1^{\mathrm{b}}$ & $10.2^{\mathrm{a}}$ & 0.10 & $10.1^{\mathrm{ab}}$ & $10.1^{b}$ & $10.3^{\mathrm{a}}$ & 0.09 & * & NS \\
\hline Fat thickness (FAT, mm) & $3.2^{\mathrm{a}}$ & $2.2^{b}$ & 0.05 & $2.8^{\mathrm{a}}$ & $2.7^{b}$ & $2.7^{\mathrm{b}}$ & 0.05 & 2.6 & 2.7 & 2.7 & 0.05 & * & * \\
\hline Fat thickness (FAT, mm) ${ }^{\mathrm{LW}}$ & 2.7 & 2.8 & 0.07 & 2.7 & 2.7 & 2.8 & 0.05 & 2.7 & 2.7 & 2.8 & 0.05 & * & NS \\
\hline
\end{tabular}

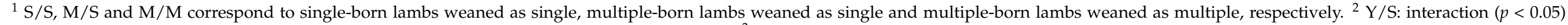

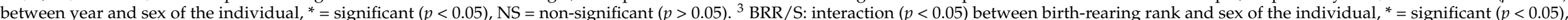

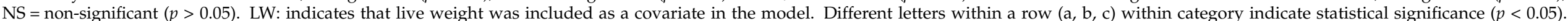
$\mathrm{SEM}=$ standard error of the mean 
Within each year, lamb LW post-shearing (321 to 438 days of age), EMA and FAT were affected by the sex of the individual $(p<0.05$, Table 5). Males had greater $(p<0.05)$ LW post-shearing, EMA and FAT than females. Ultrasound measurements were affected $(p<0.05)$ by LW at the measurements time, with interactions $(p<0.05)$ between the sex of the individual and year for both EMA and FAT. In 2010 and 2014, EMA did not differ $(p>0.05)$ between the sexes, but in all other years, males had greater EMA (5 to 23\% extra, $p<0.05)$ than females. In 2010, 2014, 2016 and 2017 FAT did not differ $(p>0.05)$ between the sexes, but in 2015 females had greater (12\% extra, $p<0.05)$ FAT than males, whereas in all other years, males had greater (10 to $15 \%$ extra, $p<0.05)$ FAT than females.

\subsection{Effects of Birth-Rearing Rank on Wool and Growth Traits}

One-year-old lamb FD was not affected by birth-rearing rank ( $p>0.05$, Table 5). There were interactions $(p<0.05)$ between birth-rearing rank and sex of the individual for GFW. Multiple-born males weaned as single had greater $(17 \%$ extra, $p<0.05)$ GFW than singleborn females. Within multiple-born lambs, males weaned as multiple produced a grater $(19 \%$ extra, $p<0.05)$ GFW than females weaned as single.

CVfd and SY were affected by birth-rearing rank $(p<0.05$, Table 5). Multiple-born lambs weaned as multiple had the greatest $(p<0.05) \mathrm{CVfd}$, with no differences $(p>0.05)$ between single-born and multiple-born lambs weaned as single. Single-born lambs had $0.6 \%$ and $1.2 \%$ greater $(p<0.05)$ SY than multiple-born lambs weaned as single and multiple-born lambs weaned as multiple, respectively. Within multiple-born lambs, SY was not affected $(p>0.05)$ by birth-rearing rank. Staple length was unaffected $(p>0.05)$ by birth-rearing rank.

There were interactions between birth-rearing rank and sex of the individual $(p<0.05)$ for lamb LW post-shearing (321-438 days of age). Multiple-born males weaned as a single had greater $(42 \%$ extra, $p<0.05) \mathrm{LW}$ post-shearing than single-born females. Multiple-born males weaned as a multiple had greater $(p<0.05)$ LW post-shearing than multiple-born females weaned as a single (39\% extra) or multiple (45\% extra). Additionally, for female LW post-shearing, there was no difference $(p>0.05)$ between single-born and those born as multiple and weaned as a single.

There was an interaction $(p<0.05)$ between the sex of the individual and birth-rearing rank for EMA. Multiple-born females weaned as single had greater $\left(0.4 \mathrm{~cm}^{2}\right.$ extra, $\left.p<0.05\right)$ EMA than single-born females, with no differences between single-born females and those weaned as multiple $\left(8.1 \pm 0.05\right.$ vs. $7.9 \pm 0.08 \mathrm{~cm}^{2}$ for $\mathrm{S} / \mathrm{S}$ and $\mathrm{M} / \mathrm{M}$ females, respectively). Within multiple-born males, EMA was not affected $(p>0.05)$ by birth-rearing rank. When live weight at the time of measurements was included in the model, multiple-born lambs weaned as multiple had the greatest $(p<0.05$, Table 5) EMA, with no differences $(p>0.05)$ between single-born and multiple-born lambs weaned as single. There was an interaction $(p<0.05)$ between the sex of the lamb and birth-rearing rank for FAT. Multiple-born males either weaned as single or multiple had greater ( 0.7 and $0.9 \mathrm{~mm}$ extra, respectively, $p<0.05)$ FAT than single-born females. When live weight at the time of measurements was included in the model, FAT was unaffected $(p>0.05)$ by birth-rearing rank.

\subsection{Effects of Age of Dam on Wool and Growth Traits}

One-year-old lamb wool traits were affected by dam age $(p<0.05$, Table 5$)$. Lambs born from 2-year-old ewes had the finest $(p<0.05)$, and those born from ewes aged 7 or older the coarsest $(p<0.05)$ fibers. Lambs born from 2-year-old ewes had lighter $(p<0.05)$ fleeces than those from 3 to 6 year-old-ewes. SL was longer $(p<0.05)$ for lambs born from 2-year-old ewes compared with those from all adult ewe groups ( $\geq 3$ years old). Lambs born from ewes aged 7 and older had lower $(p<0.05)$ SY and higher $(p<0.05)$ CVfd compared to the other two age groups.

Lamb LW post-shearing (321 to 438 days of age) was affected by dam age $(p<0.05$, Table 5). Lambs born from 2 -year-old ewes had lighter $(p<0.05)$ LW than those from all adult ewe groups $(\geq 3$ years old). EMA was affected $(p<0.05)$ by dam age. Lambs born 
from ewes aged 7 or older had greater $(p<0.05)$ EMA compared to the other two age groups. When LW at the measurement time was included in the model, lamb born from ewes aged 7 or older had greater EMA than those from 3 to 6 year-old-ewes. FAT was unaffected $(p>0.05)$ by dam age.

\subsection{Wool and Growth Traits Trends}

Over the entire study period (1999-2018), for combined male and female data, 49\% $\left(\mathrm{R}^{2}\right)$ of the phenotypic changes in one-year-old lamb FD were explained by the seconddegree polynomial regression model. The coefficient of determination for FD was greater in females $\left(R^{2}=0.57\right)$ than males $\left(R^{2}=0.39\right)$. During the establishment and FMP phases (1999-2010), FD decreased approximately $3 \mu \mathrm{m}$, whereas, in the CRILU period (2011-2018), this trait changed little (Figure 1).

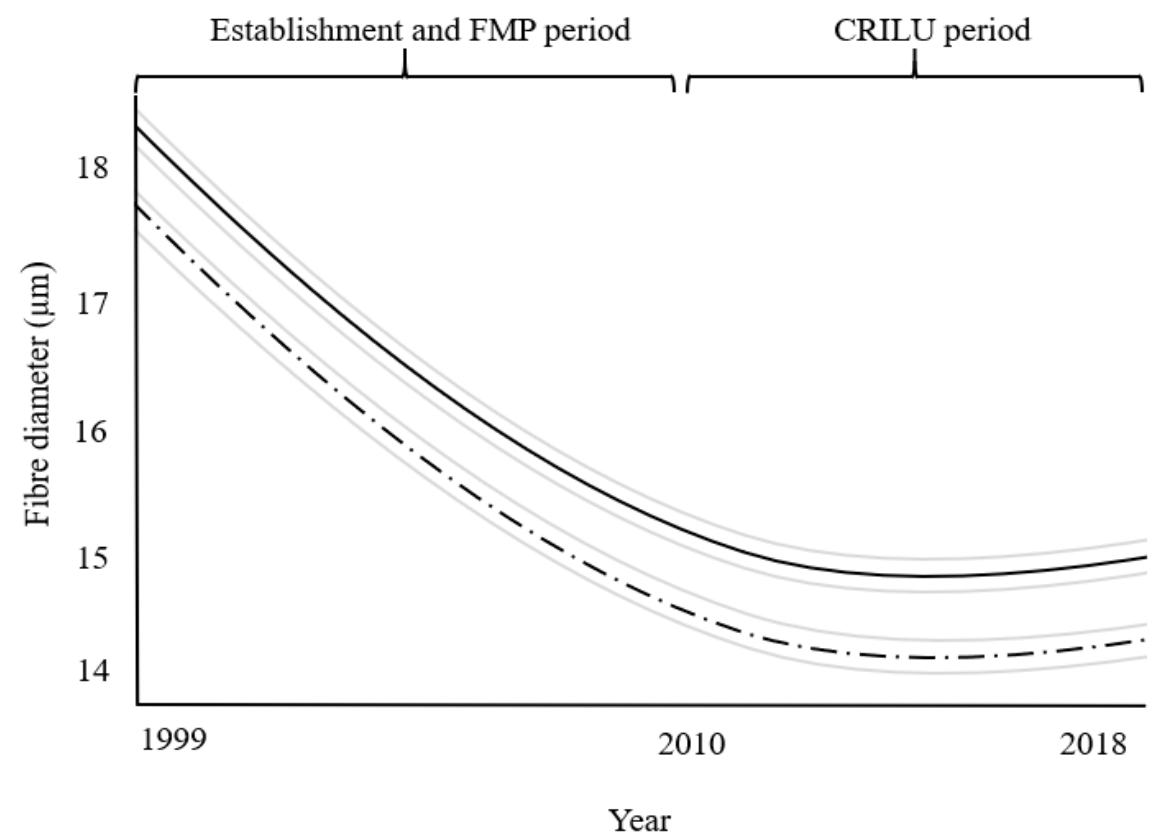

Figure 1. Male (solid line) and female (non-solid line) phenotype trends using a second-degree polynomial regression model for fiber diameter at shearing (298 to 432 days of age) across the entire study period (1999-2018). The light gray lines represent the $95 \%$ confidence limits. $R^{2}$ for the combined (male and female), male and female models were $0.49,0.39$ and 0.57 , respectively.

The third-degree polynomial regression model for the combined male and female data explained $61 \%\left(\mathrm{R}^{2}\right)$ of the phenotypic changes in one-year-old lamb GFW. The coefficient of determination $\left(\mathrm{R}^{2}\right)$ for males and females were 0.55 and 0.54 , respectively. Male and female GFW was higher at the end of the study period compared to the establishment phase (1999-2001, Figure 2). 


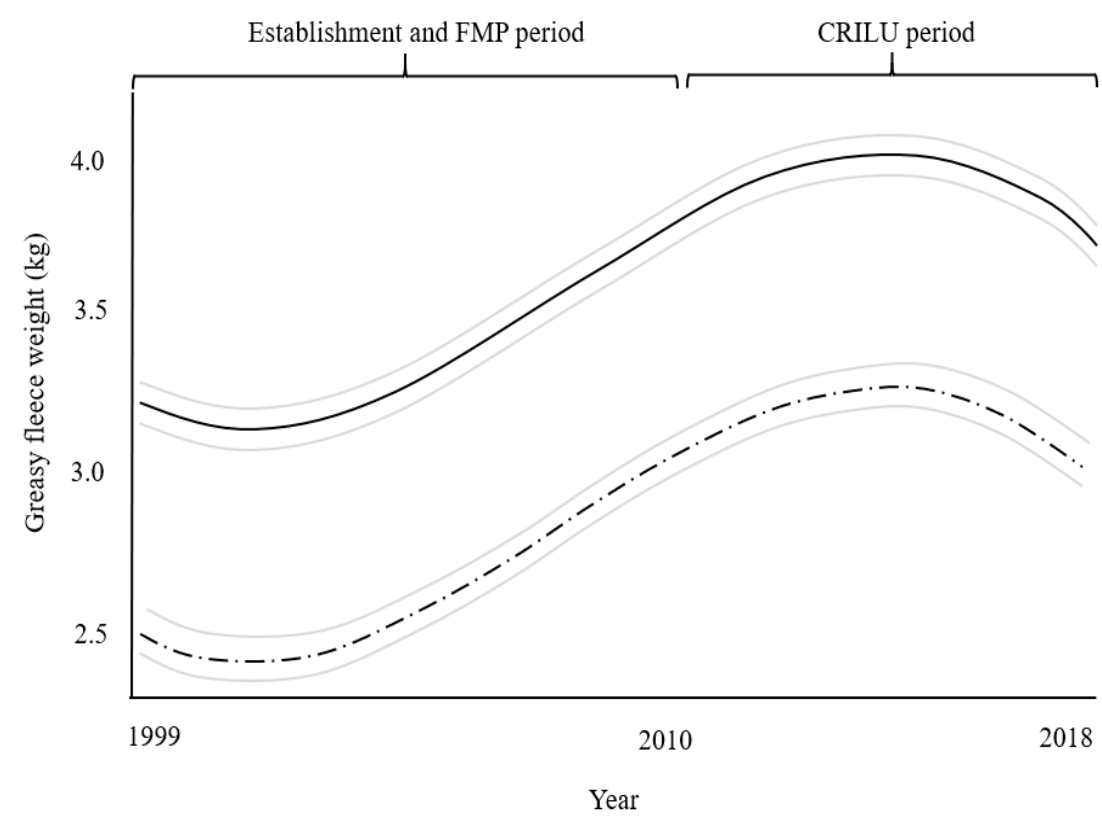

Figure 2. Male (solid line) and female (non-solid line) phenotype trends using a third-degree polynomial regression model for greasy fleece weight at shearing (298 to 432 days of age) across the entire study period (1999-2018). The light gray lines represent the $95 \%$ confidence limits. $R^{2}$ for the combined (male and female), male and female models were $0.61,0.55$ and 0.54 , respectively.

Across the entire study period, for the combined male and female data, $69 \%\left(R^{2}\right)$ of the phenotypic changes in one-year-old lamb LW post-shearing was explained by the third-degree polynomial regression model. The $\mathrm{R}^{2}$ for males and females was 0.23 and 0.25 , respectively. In both sexes, LW post-shearing at the end of the study period (2018) was heavier than the starting year (1999, Figure 3).

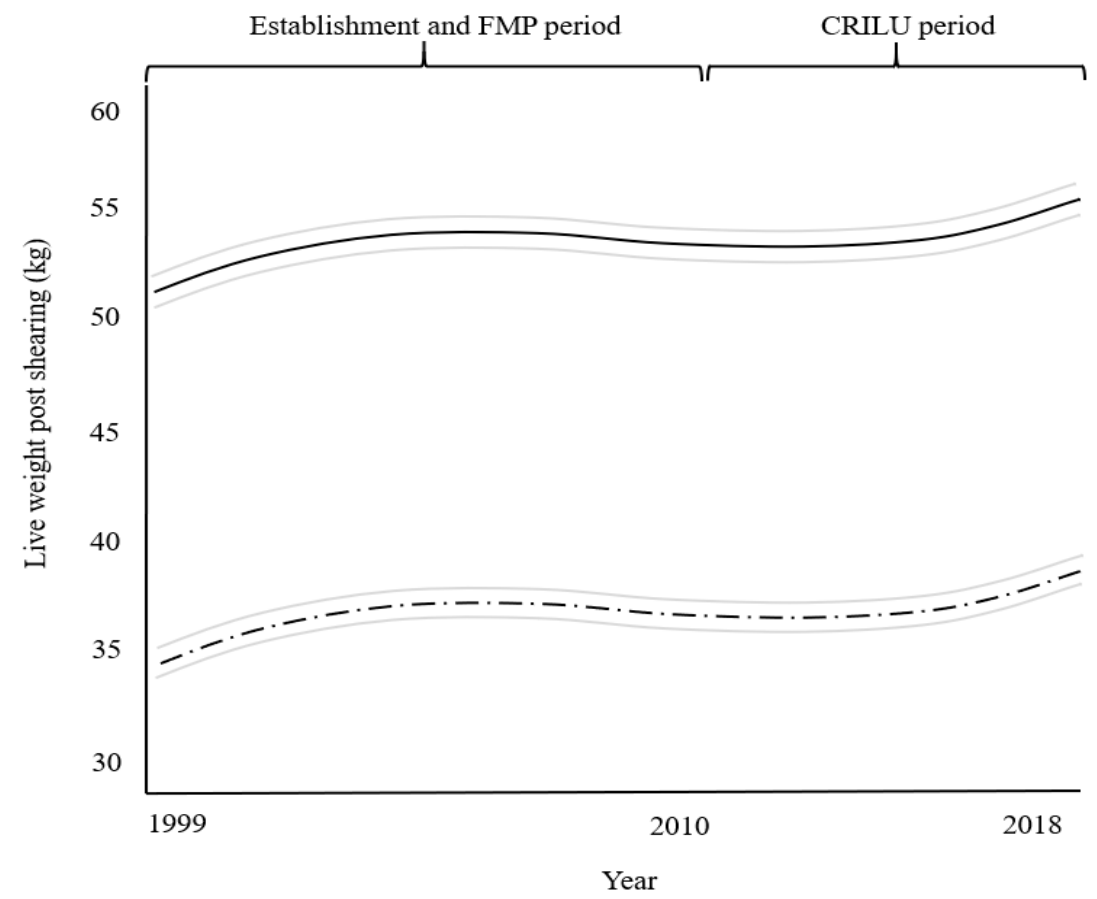

Figure 3. Male (solid line) and female (non-solid line) phenotype trends using a third-degree polynomial regression model for live weight post-shearing (321 to 438 days) across the entire study period (1999-2018). The light gray lines represent the $95 \%$ confidence limits. $R^{2}$ for the combined (male and female), male and female models were $0.69,0.23$ and 0.25 , respectively. 


\section{Discussion}

The current study combined data over the period 1999 to 2018 for the fine Merino genetic nucleus in Uruguay. The entire study period (1999-2018) was classified into three phases: Establishment (1999-2001), FMP (2002-2010), and CRILU (2011-2018). During the Establishment and FMP periods (1999-2010), the breeding objective was to reduce fiber diameter while allowing for only a slight loss in fleece weight. During the CRILU phase (2011-2018), the selection objective was to continue to reduce fiber diameter (to produce $15.5 \mu \mathrm{m}$ or finer wool) while improving both fleece weight and live weight. Overall, the objectives of the FMP and CRILU were successful.

During the Establishment and FMP periods (1999-2010), one-year-old female and male FD decreased by approximately $3 \mu \mathrm{m}$, from 18 to $15 \mu \mathrm{m}$, which is consistent with previously reported reductions in FD in other Merino selection flocks [26-28]. This phenotypic progress in FD can be partially explained by the application of the selection index [29,30], the high heritability (0.73) of FD [18] and the inclusion of overseas genetic material. In Uruguay, reducing FD from 21 to $17 \mu \mathrm{m}$ could increase sheep farmer income by approximately $70 \%$ [31]. Combined, these data indicate selection for reduced FD should increase farmer income in less than 10 years.

Improvement in animal economic worth generally requires selection for several traits simultaneously [32,33]. During the CRILU phase (2011-2018), the selection index utilized combined EBVs for FD, CFW and LW. In this period, one-year-old female and male phenotypic FD remained below $16 \mu \mathrm{m}$, with little apparent change in FD occurring over time. This outcome is likely due to the unfavorable genetic correlations between FD and both CFW and LW, making it harder to improve these traits jointly $[34,35]$. Despite this, the breeding objective for FD of the fine Merino genetic nucleus (to produce $15.5 \mu \mathrm{m}$ or finer wool) was still achieved. This finding is supported by others $[28,29,36]$, who have reported that the maintenance or reduction in phenotypic FD can be made when animals are also selected for increased CFW and LW, as the unfavorable correlations between FD and both traits are only moderate (0.19 and 0.22 , respectively) [18]. Little apparent change in FD towards the end of the study period was expected, given that the breeding objective for this trait had already been achieved.

Fiber diameter, greasy fleece weight, and live weight are the most important production traits in Merino flocks [30]. In the current study, reductions in lamb phenotypic FD were accompanied by increases of more than $0.5 \mathrm{~kg}$ in phenotypic GFW, which is consistent with previously reported in Merino sheep after 10 years of selection [28]. Across the entire study period, phenotypic LW post-shearing increased by approximately $3 \mathrm{~kg}$, which likely contributed to increased GFW [37]. The change in the selection objective in the CRILU period, including LW in the selection index, as well as changes in the emphases in FD and GFW, is reflected in the phenotypic trends of these traits. The findings show, therefore, that by using suitable selection indexes, farmers can obtain favorable phenotypic changes in the desired economic wool and growth traits.

Phenotypic changes in FD can also occur through non-genetic factors, such as nutritional conditions $[38,39]$. In our study, a better nutrition status in males was associated with coarse fibers, which is consistent with a positive relationship between nutrition and FD reported by others $[24,40,41]$. Interactions between the sex of the lamb and the year for this trait could potentially be explained by fluctuations in annual rainfall, which influences pasture growth in Uruguay [14], as well as differences in the proportion of males/females by a given sire. In addition, a higher FD in males in our study can also likely be explained by testosterone $[42,43]$.

Factors, such as birth type and dam age, also influence phenotypic lamb FD [38], although the effect of birth rank on this trait is unclear [44]. Some studies have shown that multiple-born animals tend to produce coarser wool than singletons [45,46]. However, in our study, as previously reported [47], birth-rearing rank did not show any significant effect on lamb FD. A potential poorer prenatal nutrition of the fetus(es)/lamb(s) from young dams maybe result in coarser fibers [48,49]. However, earlier findings [50] reported no effect 
of the dam age on lamb FD. In our study, lambs from 2-year-old ewes had finer wool than those from adult ewes ( $\geq 3$ years old), which is consistent with others [51], who reported finer wool in ewe lamb offspring. The between studies differences related to the effect of the dam age and birth-rearing rank on lamb FD could potentially be associated with variation in ewe LW at mating and ewe LW gain during gestation, including nutritional status all, of which can affect progeny FD [48,52]. In addition, in our study, the effect of the dam age on lamb FD may be influenced by differences in genetic merit for FD between young and older dams, where younger dams are expected to be finer.

A lamb's wool production depends on maternal nutrition [18,53]. Insufficient supply of nutrients during the fetal and pre-weaning phases can reduce the number of secondary follicles resulting in lighter fleeces $[48,49]$. In the present study, lambs from two-year-old ewes had 3.5\% lighter fleece than those from three-to-six-year-old ewes, which is consistent with those reported by others $[45,50]$ in Merino sheep. This result can be explained by the young dam using nutrients for her own growth, resulting in reduced fetal and secondary follicle development [54]. It can also be explained by lower milk production in a young dam [55]. Unsurprisingly, in our study, multiple weaned lambs had lower phenotypic GFW than single-born lambs, which is consistent with earlier findings [45]. This result is likely explained by low birth weight and lower growth rates pre-weaning in multiple weaned lambs, which result in lighter fleeces [44,48].

The wool and body growth of grazing sheep depends largely on their genetic potential and nutritional status $[24,35,41]$. In the present study, males had heavier phenotypic GFW than females, which is coincident with earlier findings [50,54]. Our males were managed on improved pasture plus supplement feeding as required, whereas, in females, the nutrition was mostly based on native pasture. Therefore, higher wool productivity in males compared to females in our study is most likely explained by their better nutritional status during the post-weaning phase (from weaning to shearing) $[24,41]$. Increased phenotypic GFW in males in the present study was accompanied by heavier LW [37]. In addition to nutritional conditions, differences in GFW, LW and post-mortem EMA between sexes are hormonally driver $[54,56,57]$. These findings indicate the importance of considering both sexes of the lamb and management group when animals are phenotypically compared.

Greater income through increased meat production is becoming more important in many Merino sheep production systems [58]. Live weight and ultrasound measurements of muscle and subcutaneous fat are key indicator traits of meat yield and fat content [59]. In the present study, heavier phenotypic LW in males was associated with greater phenotypic FAT and EMA, agreeing with others [24,60]. Undernutrition during early fetal life influences muscle development [61]. In addition, during early life, multiple-born lambs receive less milk than their singleton-born counterparts, which in turn also limits their growth rates [62]. In our study, multiple weaned lambs had lower phenotypic EMA than single weaned lambs, which was explained by differences in LW at the time of measurements. This agrees with earlier findings [63], who reported lower carcass weights in twins than singletons. In addition, the age of the dam influences adipose tissue growth in offspring, with the lowest fat deposition being for lambs from young ewes [64]. However, in our study, as previously reported [60], there was no effect of dam age on lamb fat content. In the present study, lambs from 2-year-old ewes were lighter and had lower phenotypic EMA than those from ewes aged seven and older, which is coincident with others [65]. This result can be explained by the lighter birth weight of the lamb and the lower lactational performance of the young dam $[44,55]$.

\section{Conclusions}

In conclusion, this study demonstrates that the genetic selection process applied in the fine Merino genetic nucleus over the 1999 to 2018 period resulted in phenotypic improvements in one-year-old female and male wool and growth traits. The results indicate that by using suitable selection indexes, reductions of approximately $3 \mu \mathrm{m}$ in phenotypic FD (from 18 to $15 \mu \mathrm{m}$ ) and increases in both greasy fleece weight (at least $0.5 \mathrm{~kg}$ ) and live 
weight (approximately $3 \mathrm{~kg}$ ) can be obtained. Therefore, this project demonstrates it is possible to produce ultrafine wool without compromising other economically relevant traits in Uruguayan yearling lambs. These results, if transferred to the Uruguayan sheep industry, will increase farmer income.

Author Contributions: Conceptualization, H.T.B., P.R.K., I.D.B., G.C., F.M. and Z.R.; data collection, F.M., I.D.B. and Z.R.; formal analysis and supervision, H.T.B. and P.R.K.; analysis, results in interpretation, and preparation of the manuscript, Z.R.; writing—-review and editing, H.T.B., P.R.K., I.D.B., G.C. and F.M. All authors have read and agreed to the published version of the manuscript.

Funding: This research was funded by the National Institute for Agriculture Research (INIA) and Regional Consortium for Innovation in Ultrafine Wool (CRILU). This study was supported by two Ph.D. scholarships (from the National Agency for Investigation and Innovation of Uruguay, ANII, and from Massey University, New Zealand) awarded to Zully Ramos.

Institutional Review Board Statement: The study was approved by INIA Animal Ethics Committee (Approval numbers INIA_2018.2).

Informed Consent Statement: Not applicable.

Data Availability Statement: The data presented in this study are available within the article.

Acknowledgments: The authors thank the assistance of all staff of Glencoe Experimental Unit, INIA Tacuarembó, SUL, SCMAU, INIA and CRILU.

Conflicts of Interest: The authors declare no conflict of interest. The funders approved the design of the study but had no role in the collection, analyses or interpretation of data, in the writing of the manuscript or in the decision to publish the results.

\section{References}

1. Cardellino, R.C.; Salgado, C.; Azzarini, M. La producción ovina y lanera en Uruguay. In Proceedings of the IV Congreso Mundial del Merino, Montevideo, Uruguay, 20-22 April 1994; Azzarini, M., Cardellino, R.C., Eds.; Talleres gráficos de El Pais S.A. pp. 37-52.

2. Cardellino, R.C.; Salgado, C. Wool production and marketing in South America. Wool Technol. Sheep Breed. 1990, $38,13-20$.

3. Champion, S.C.; Fearne, A.P. Alternative marketing systems for the apparel wool textile supply chain: Filling the communication vacuum. Int. Food Agribus. Manag. Rev. 2001, 4, 237-256. [CrossRef]

4. Trewin, D. Year Book Australia, 84th ed.; Australian Bureau of Statistics Canberra ABS: Belconnen, Australia, 2002 ; pp. 477-479.

5. Banks, R.; Brown, D. Genetic improvement in the Australasian Merino: Management of a diverse gene pool for changing markets. Anim. Genet. Resour. Inf. 2009, 45, 29-36. [CrossRef]

6. Wool Industry-National RD and E Strategy 2018-2022; Australian Wool Innovation Ltd.: London, UK, 2018; pp. 1-70. Available online: https: / www.wool.com (accessed on 15 May 2020).

7. Pattinson, R.; Wilcox, C.H.; Williams, S.; Curtis, K. Wool Industry and Future Opportunities; Department of Primary Industry: Perth, Australia, 2015; pp. 1-69. Available online: https:/ /www.dpi.nsw.gov.au/ (accessed on 20 May 2020).

8. Economic Analysis of Sheep Production Systems; Hassall and Associates Pty Ltd. (Ed.) Meat and Livestock Australia Limited: Sydney, Australia, 2004; pp. 1-28. Available online: https:/ /www.mla.com.au (accessed on 20 May 2020).

9. Nolan, E.; Farrell, T.; Ryan, M.; Gibbon, C.; Ahmadi-Esfahani, F.Z. Valuing quality attributes of Australian Merino wool. Aust. J. Agric. Res. Econ. 2013, 58, 314-335. [CrossRef]

10. Cardellino, R.; Wilcox, C.; Trifoglio, J.L. El Mercado de la Lana y su Efecto en la Producción Ovina Uruguaya. 2018, pp. 22-24. Available online: http:/ / actualidadagropecuaria.com.uy (accessed on 20 May 2020).

11. Montossi, F.; De Barbieri, I.; Ciappesoni, G.; de Mattos, D.; Mederos, A.; Luzardo, S.; Soares de Lima, J.M.; de los Campos, G.; Nolla, M.; Julián, R.S.; et al. Los Productos Logrados en los Primeros 8 Años (1998-2006) de Existencia del Proyecto Merino Fino del Uruguay: Una Visión con Perspectiva Histórica. In Proyecto Merino Fino del Uruguay: Una Visión con Perspectiva Histórica; Boletín de Divulgación INIA 90; Montossi, F., De Barbieri, I., Eds.; Unidad de Comunicación y Transferencia de Tecnología: Montevideo, Uruguay, 2007; pp. 17-36.

12. Montossi, F.; De Barbieri, I.; Ciappesoni, G.; Ravagnolo, O.; De Mattos, D.; Pérez Jones, J.; Soares de Lima, M. Núcleo fundacional de Merino fino y superfino de la unidad experimental Glenoce-INIA Uruguay: Una experiencia innovadora de mejoramiento genético asociativo y participativo. Agrociencia 2005, 9, 609-616.

13. Montossi, F.; De Barbieri, I.; Ciappesoni, G.; Ramos, Z.; Donagaray, F.; Silva, J.; Fros, A.; Perez, J.; Dutra, F.; Soares de Lima, M.J.; et al. Avances y productos obtenidos. In Alternativas Tecnológicas Para Sistemas Ganaderos del Basalto; Serie Técnica INIA, 217; Berretta, E., Montossi, F., Brito, G., Eds.; Unidad de Comunicación y Transferencia de Tecnología: Montevideo, Uruguay, 2014; pp. 385-404. 
14. Berretta, E. Principales características climáticas y edáficas de la región de basalto en Uruguay. In Seminario de Actualización en Tecnologías para Basalto; Serie Técnica INIA, 102; Berretta, E., Ed.; Unidad de Comunicación y Transferencia de Tecnología: Montevideo, Uruguay, 1998; pp. 3-10.

15. Berretta, E.; Risso, D.; Montossi, F.; Pigurina, G. Campos in Uruguay. Grassland Ecophysiol. Grazing Ecol. 2000, 377-394. [CrossRef]

16. Visual Sheep Scores; Australian Wool Innovation Ltd.: Sydney, Australia, 2013; pp. 1-57. Available online: https://www.wool.com (accessed on 21 April 2020).

17. Consideraciones y Aspectos Prácticos a Tener en Cuenta al Definir los Vientres de Reposición. Manual Práctico de Producción Ovina; Secretariado Uruguayo de la Lana (SUL): Montevideo, Uruguay, 2018; pp. 220-222.

18. Ciappesoni, G.; Goldberg, V.; Gimeno, D. Estimates of genetic parameters for worm resistance, wool, and growth traits in Merino sheep of Uruguay. Livest. Sci. 2013, 157, 65-74. [CrossRef]

19. Ciappesoni, G. ¿Cómo elegir un carnero? Entendiendo la información genética disponible. Revista INIA 2014, $39,23-27$.

20. Ciappesoni, G.; Gimeno, D.; Coronel, F. Nuevos Índices de selección Merino: La genética en dólares. Revista SUL 2012, 161, 24.

21. Ramos, Z.; Montossi, F. Alternativas tecnológicas para aumentar la supervivencia de corderos: Control Integrado de Parición en Ovinos. Revista INIA 2014, 38, 11-15.

22. Sheep Standards and Guidelines Writing Group. Sheep Standards and Guidelines-Tail Docking. 2013, pp. 1-17. Available online: http:/ / www.animalwelfarestandards.net.au/ (accessed on 20 April 2020).

23. Langlands, P.; Wheeler, L. The dyebanding and tattooed parch procedures for estimating wool production and obtaining samples for the measurements of fibre diameter. Anim. Prod. Sci. 1968, 8, 265-269. [CrossRef]

24. Ramos, Z.; De Barbieri, I.; Van Lier, E.; Montossi, F. Body and wool growth of lambs grazing on native pastures can be improved with energy and protein supplementation. Small. Rumin. Res. 2019, 171, 92-98. [CrossRef]

25. Abella, I.; Cardellino, R.C.; Mueller, J.; Cardellino, R.A.; Benítez, D.; Lira, R. South American Sheep and Wool Industries. In International Sheep and Wool Handbook; Cottle, D.J., Ed.; Nottingham University Press: Nottingham, UK, 2010; pp. 85-94.

26. Swan, A.A.; Purvis, I.W. Genetic progress in the T13 Merino breeding program. In Proceedings of the Association for the Advancement of Animal Breeding and Genetics, Noosa, Australia, 25-28 September 2005; pp. 165-168.

27. Greeff, J.C.; Cox, G. Genetic changes generated within the Katanning Merino Resource flocks. Aust. J. Exp. Agric. 2006, 46, 803-808. [CrossRef]

28. Taylor, P.; Bird-Gardiner, T.; Mortimer, S.; Atkins, K. Selection Indexes Work for All Merino Strains and Breeding Objectives; Department of Primary Industry: Perth, Australia, 2007. Available online: https:/ / www.dpi.nsw.gov.au (accessed on 1 October 2020).

29. Taylor, P.; Mortimer, S.; Bird-Gardiner, T.; Atkins, K. Merino Breeding Objectives and Selection Indexes to Increase Wool Profit; Department of Primary Industry: Perth, Australia, 2007. Available online: https:/ / www.dpi.nsw.gov.au (accessed on 1 October 2020).

30. Safari, E.; Fogarty, N.M.; Gilmour, A.R. Sensitivity of response of multi-trait index selection to changes in genetic correlations between production traits in sheep. Aust. J. Exp. Agric. 2006, 46, 283-290. [CrossRef]

31. Buffa, I.; Soares de Lima, J.M.; Carrquiry, E. Mejora en la Competitividad en la Región de Basalto; Octava Jornada de Distribución de Reproductores CRILU: Tacuarembó, Uruguay, 2017; Available online: http: / / www.inia.uy (accessed on 20 September 2020).

32. Hazel, L.N.; Dickerson, G.E.; Freeman, A.E. The selection index then, now, and for the future. J. Dairy. Sci. 1994, 77, 3236-3251. [CrossRef]

33. Safari, E.; Fogarty, N.M.; Gilmour, A.R. A review of genetic parameter estimates for wool, growth, meat and reproduction traits in sheep. Livest. Prod. Sci. 2005, 92, 271-289. [CrossRef]

34. Van der Werf, J.H.J. Multiple Trait Selection. 2009. Available online: https:/ /www.woolwise.com (accessed on 10 October 2020).

35. Masters, D.G.; Ferguson, M.B. A review of the physiological changes associated with genetic improvement in clean fleece production. Small Rumin. Res. 2019, 170, 62-73. [CrossRef]

36. Fogarty, N.M.; Safari, E.; Gilmour, A.R.; Ingham, V.M.; Atkins, K.D.; Mortimer, S.I.; Swan, A.A.; Brien, F.D.; Greeff, J.C.; van der Werf, J.H.J. Wool and meat genetics-The joint possibilities. Int. J. Sheep Wool Sci. 2006, 54, $22-27$.

37. Mortimer, S.I.; Hatcher, S.; Fogarty, N.M.; Van Der Werf, J.H.J.; Brown, D.J.; Swan, A.A.; Greeff, J.C.; Refshauge, G.; Edwards, J.H.; Gaunt, G.M. Genetic parameters for wool traits, live weight, and ultrasound carcass traits in Merino sheep. J. Anim. Sci. 2017, 95, 1879-1891. [CrossRef] [PubMed]

38. Greeff, J.; Kinghorn, B.P.; Brown, D. Breeding and selection. In International Sheep and Wool Handbook; Cottle, D.J., Ed.; Nottingham University Press: Nottingham, UK, 2010; pp. 165-188.

39. McGregor, B.A.; Butler, K.L. Coarser wool is not a necessary consequence of sheep aging: Allometric relationship between fibre diameter and fleece-free liveweight of Saxon Merino sheep. Animal 2016, 10, 2051-2060. [CrossRef] [PubMed]

40. McGregor, B.A. Influence of stocking rate and mixed grazing of Angora goats and Merino sheep on animal and pasture production in southern Australia. 3. Mohair and wool production and quality. Anim. Prod. Sci. 2010, 50, 168-176. [CrossRef]

41. Khan, M.J.; Abbas, A.; Ayaz, M.; Naeem, M.; Akhter, M.S.; Soomro, M.H. Factors affecting wool quality and quantity in sheep. Afr. J. Biotechnol. 2012, 11, 13761-13766. [CrossRef]

42. Rather, M.A.; Shanaz, S.; Ganai, N.A.; Bukhari, S.; Hamadani, A.; Khan, N.N.; Yousuf, S.; Baba, A.; Raja, T.A.; Khan, H.M. Genetic evaluation of wool traits of Kashmir Merino sheep in organized farms. Small Rumin. Res. 2019, 177, 14-17. [CrossRef]

43. Nazari-Zonouz, F.; Moghaddam, G.; Rafat, S.A.; Abdi, Z.; Etemad Gorgan, K.; Nabavi, R. The effect of prepubertal castration on wool diameter and blood testosterone in ghezel breed. Iran. J. Appl. Anim. Sci. 2018, 8, 635-639. 
44. Kenyon, P.R.; Blair, H.T. Foetal programming in sheep-effects on production. Small Rumin. Res. 2014, 118, 16-30. [CrossRef]

45. Safari, E.; Fogarty, N.M.; Gilmour, A.R.; Atkins, K.D.; Mortimer, S.I.; Swan, A.A.; Brien, F.D.; Greeff, J.C.; Van der Werf, J.H.J. Across population genetic parameters for wool, growth, and reproduction traits in Australian Merino sheep. 1. Data structure and non-genetic effects. Aust. J. Agric. Res. 2007, 58, 169-175. [CrossRef]

46. Ciappesoni, G.; Gimeno, D.; Coronel, F. Progreso genético logrado en las evaluaciones ovinas del Uruguay. Arch. Latinoam. Prod. Anim. 2014, 22, 73-80.

47. Eltawil, E.A. Genetic and Environmental Factors of Sheep Under Arid Conditions. Ph.D. Thesis, Iowa State University, Ames, IA, USA, 1965.

48. Thompson, A.N.; Ferguson, M.B.; Gordon, D.J.; Kearney, G.A.; Oldham, C.M.; Paganoni, B.L. Improving the nutrition of Merino ewes during pregnancy increases the fleece weight and reduces the fibre diameter of their progeny's wool during their lifetime and these effects can be predicted from the ewe's liveweight profile. Anim. Prod. Sci. 2011, 51, 794-804. [CrossRef]

49. Kelly, R.W.; Greeff, J.C.; Macleod, I. Lifetime changes in wool production of Merino sheep following differential feeding in fetal and early life. Aust. J. Agric. Res. 2006, 57, 867-876. [CrossRef]

50. Wuliji, T.; Dodds, K.G.; Land, J.T.J.; Andrews, R.N.; Turner, P.R. Response to selection for ultrafine Merino sheep in New Zealand: Wool production and wool characteristics of ultrafine fibre diameter selected and control Merino yearlings. Livest. Prod. Sci. 1999, 58, 33-44. [CrossRef]

51. Thompson, A.; Young, J. Improving the Reproductive Performance of Ewe Lambs-Management Guidelines, Economic Analysis, and Decision Support Tools; Meat and Livestock Australia Limited: Sydne, Australia, 2018; pp. 1-42. Available online: https: / / www.mla.com.au (accessed on 10 July 2020).

52. McGregor, B.A.; De Graaf, S.P.; Hatcher, S. On-farm factors affecting physical quality of Merino wool. 1. Nutrition, reproduction, health and management. Small. Rumin. Res. 2016, 137, 138-150. [CrossRef]

53. Lewis, R.M.; Beatson, P.R. Choosing maternal-effect models to estimate (co) variances for live and fleece weight in New Zealand Coopworth sheep. Livest. Prod. Sci. 1999, 58, 137-150. [CrossRef]

54. Di, J.; Zhang, Y.; Tian, K.C.; Liu, J.F.; Xu, X.M.; Zhang, Y.J.; Zhang, T.H. Estimation of (co) variance components and genetic parameters for growth and wool traits of Chinese superfine merino sheep with the use of a multi-trait animal model. Livest. Sci. 2011, 138, 278-288. [CrossRef]

55. Geenty, K.G. Lactation and lamb growth. In International Sheep and Wool Handbook; Cottle, D.J., Ed.; Nottingham University Press: Nottingham, UK, 2010; pp. 259-276.

56. Schanbacher, B.D.; Crouse, J.D.; Ferrell, C.L. Testosterone influences on growth, performance, carcass characteristics and composition of young market lambs. J. Anim. Sci. 1980, 51, 685-691. [CrossRef]

57. Mahmood, A.B.; Al-Obaidi, A.S.; Omar, C.A. Some carcass traits and meat chemical characteristics of karadi lambs injected with testosterone enanthate. IOP Conf. Ser. Earth Environ. Sci. 2019, 388, 1-8. [CrossRef]

58. Rowe, J.B. The Australian sheep industry-undergoing transformation. Anim. Prod. Sci. 2010, 50, 991-997. [CrossRef]

59. Greeff, J.C.; Safari, E.; Fogarty, N.M.; Hopkins, D.L.; Brien, F.D.; Atkins, K.D.; Mortimer, S.I.; Van Der Werf, J.H.J. Genetic parameters for carcass and meat quality traits and their relationships to liveweight and wool production in hogget Merino rams. J. Anim. Breed. Genet. 2008, 125, 205-215. [CrossRef]

60. Romdhani, S.B.; Djemali, M. Estimation of sheep carcass traits by ultrasound technology. Livest. Sci. 2006, 101, 294-299. [CrossRef]

61. Daniel, Z.C.T.R.; Brameld, J.M.; Craigon, J.; Scollan, N.D.; Buttery, P.J. Effect of maternal dietary restriction during pregnancy on lamb carcass characteristics and muscle fiber composition. J. Anim. Sci. 2007, 85, 1565-1576. [CrossRef]

62. Moffatt, C. Can lambs compensate for less milk by grazing more often. In Proceedings of the New Zealand Grassland Association Conference, West Coast, New Zealand, 1 June 2002; pp. 103-106. [CrossRef]

63. McCoard, S.A.; Koolaard, J.; Charteris, A.; Luo, D. Effect of Twinning and Sex on Carcass Weight and Composition in Lambs; New Zealand Society of Animal Production: Palmerton North, New Zealand, 2010; pp. 133-136.

64. Symonds, M.E.; Pearce, S.; Bispham, J.; Gardner, D.S.; Stephenson, T. Timing of nutrient restriction and programming of fetal adipose tissue and development. Proc. Nutr. Soc. 2004, 63, 397-403. [CrossRef] [PubMed]

65. Loureiro, M.F.P.; Paten, A.M.; Asmad, K.; Pain, S.J.; Kenyon, P.R.; Pomroy, W.E.; Scott, I.; Blair, H.T. Brief Communication: The effect of dam age and lamb birth rank on the growth rate, faecal egg count and onset of puberty of single and twin female offspring to 12 months of age. In Proceedings of the New Zealand Society of Animal Production, Invercargill, New Zealand, 29 June-1 July 2011; pp. 83-85. 